\title{
Current Situation, Problems and Countermeasures of Cross-border E-commerce in Fujian Free Trade Area
}

\author{
Siwei Dai \\ Fuzhou University of International Studies and Trade 350202
}

\begin{abstract}
The establishment of Free Trade Area has brought new opportunities and challenges for the development of crossborder e-commerce. This paper first analyzes the current situation of cross-border e-commerce in Free Trade Area, and then analyzes several exiting problems such as unbalanced development in three areas, lack of supervision, imperfect logistics and lack of interdisciplinary talents. In conclusion, this paper proposes suggestions and resolutions for the existing problems.
\end{abstract}

Keywords-Fujian; Free Trade Area; Cross-border Ecommerce; Foreign trade

\section{INTRODUCTION}

The economy in Fuzhou develops rapidly and highly export-oriented. The establishment of Fujian Free Trade Area has brought new opportunities for the development of crossborder e-commerce. Fuzhou and Pingtan are pilot cities of developing cross-border e-commerce. China has issued relative urban policy and preferential policy to support the development of cross-border e-commerce, clear away obstacles and provide favorable environment for the cross-border e-commerce development.

\section{CURRENT SituATION OF CROSS-BORDER E-COMMERCE IN FUJIAN FREE TRADE AREA}

\section{A. Steadily Enhance Transaction Volume}

In recent years, China's e-commerce has developed rapidly, the transaction volume of e-commerce is on the rise, and the total transaction volume of cross-border e-commerce has increased year by year. The cross-border e-commerce transaction volume in Fujian Province has also shown a "steadily rising" trend in recent years. From 2013 to 2017, the total transaction volume increased from 3200 billion yuan to 7600 billion yuan, and the proportion of transaction volume of cross-border e-commerce in the national total volume remained stable, maintaining around $30 \%$. It is shown that the crossborder e-commerce has developed very well; in recent years, ecommerce in Fujian Province has also flourished, and the ecommerce transaction volume has exceeded the trillion-yuan in 2016. The transaction volumes of cross-border e-commerce have been increasing continuously, from 2013 to 2017 , the transaction volume of cross-border e-commerce increased from 78 billion yuan to more than 300 billion yuan. Compared with the unfavorable situation of traditional foreign trade, the average growth of cross-border e-commerce has remained stable at $30 \%$ in recent years, and the proportion it takes up in China is also growing. The rapid development of cross-border e-commerce in Fujian Province is in sharp contrast to the unfavorable situation of traditional foreign trade, but it also drives the development of traditional foreign trade in Fujian Province.

\section{B. Product Diversification}

In 2015, for China's export cross-border e-commerce, the sellers of Fujian accounted for $9.4 \%$ of total sellers, ranking fourth in the country. At present, the main export products of Fujian Province, such as electronic information, electromechanical products, home \& gardening, textiles, etc., are consistent with the hot products on the four large crossborder e-commerce platforms. According to the data, in 2017, among categories and national regions Fujian Province's crossborder e-commerce retail export to through eBay, the top three countries are the United States, Australia and the United Kingdom; the top five best-selling products are apparel accessories, sporting goods, household appliances, auto parts and office supplies.

\section{Great Driving Effect of Leading Enterprises}

In 2017, the Rookie Network officially landed in Fuzhou, which marked that the payment information push problem will be solved, and the merchant resources will be introduced through Tmall Global and other e-commerce platforms. In 2018, eBay, one of the world's largest e-commerce trading platforms, set branch office in Fuzhou. The first exclusive industrial park in the world, the eBay Cross-border Ecommerce Industrial Park was established in Fuzhou. The establishment of the Cross-border E-commerce Industrial Park will improve the cross-border e-commerce industry chain and promote the agglomeration of e-commerce enterprises. Foreign leading enterprises have contributed to the development of cross-border e-commerce in the Fujian Free Trade Area. The strength of Fujian's local cross-border e-commerce enterprises has been continuously enhanced and its scale has been continuously expanded. Foreign leading enterprises and local leading enterprises in Fujian have driven the rapid development of cross-border e-commerce in the Free Trade Area. The Fujian Free Trade Area attaches great importance to the introduction and cultivation of cross-border e-commerce leading enterprises, so that they can play a driving role and enhance the competitiveness of the entire industrial chain. 


\section{The EXITING PROBlems OF CROSS-BORDER E- COMMERCE IN FUJIAN FREE TRADE AREA}

\section{A. Unbalanced Development in Three Areas}

As provincial capital of Fujian, Fuzhou has strong industrial and software industry foundation. Jiangyin and Mawei Port develop mixed type of cross-border e-commerce. Xiamen, is a city on the mainline of shipping line, is adjacent to the advanced manufacturing base in Golden Triangle in southern Fujian. Its shipping environment and clearance environment attract many enterprises conducting import and export businesses. Pingtan is weak in development. It did not effectively take advantage of its geographical conditions, so there is a gap between Pingtan and the other two areas. There is homogenization and similar functions in industries between the three areas. The three areas lack joint management.

\section{B. Imperfect Supervisory System}

With the rapid development of cross-border e-commerce, there are many counterfeit goods flowing into the market, and the quality of the products is worrying. Some domestic suppliers of forge counterfeit goods, invoice and delivery addresses; some purchase packaging boxes from the buyers purchasing genuine goods, etc.; in fact, the counterfeit products are produced by small domestic workshops, the production site is mess and dirty, the cost is extremely low and the materials are not in conformity with national standards and may even damage human health. However, there are counterfeit and shoddy products flowing into market constantly.

The imported goods are transported through the warehouse in bonded area or direct mail from overseas. When entering into and coming out of the bonded warehouse, the product is not subject to inspection and quarantine, which leads to the inflow of the unqualified goods. The Internet changes global trade. Small and micro businesses and cross-border online shopping are more and more popular. The customized small packages replaced freight containers. Petty and individualized type of trading replaced mass and standardized traditional way. The formal customer clearance and inspection system of traditional large amount of foreign trade is inapplicable to cross-border e-commerce.

\section{Imperfect Logistics Facility Construction}

The imperfect facility construction is a key factor which refrain the development of cross-border e-commerce in Fujian Free Trade Area. There are several problems, such as low degree of automation of logistics center, warehouse and storage, imperfect functions and defects in gather and distribute, etc. Furthermore, as coastal cities, the three areas of Fujian Free Trade Area did not give full play to its advantages. The freight volume transported by waterways and air is low, and the proportion of freight volume transported by air is lower. Lack ports to collect and distribute goods. The railway advantage has not been fully utilized. The logistics and transportation methods are single and not diverse.

\section{Shortage of Talents}

Cross-border e-commerce industry covers a wide range of areas, including culture, finance, logistics, trade, services, etc. One of the outstanding characteristics of talents needed by cross-border e-commerce is internationalization. They shall be knowledgeable, not only for professional knowledge, but also for foreign languages, foreign trade knowledge, marketing, ecommerce, and laws and regulations. At present, the crossborder e-commerce industry in Fujian Free Trade Area lacks of interdisciplinary talents who are familiar with specialized knowledge and have a better understanding of the knowledge in relevant industries. There is a large shortage of talents in cross-border e-commerce.

\section{COUNTERMEASURES OF CROSS-BORDER E-COMMERCE DEVELOPMENT IN FUJIAN FREE TRADE AREA}

\section{A. Deepen Cooperation of Three Areas}

The three areas have their own advantages. Xiamen is one of the pioneer of special economic Areas with favorable shipping environment and clearance environment; as provincial capital, Fuzhou has many opportunities and attracts many enterprises and platforms of cross-border e-commerce. It is necessary to enlarge the Cross-border E-commerce Industrial Park in Fuzhou; Pingtan is the close neighbor of Taiwan across the sea, it shall take advantage of its geographical conditions and attract foreign cross-border e-commerce enterprises. The three areas shall make use of their advantages and promote the development of cross-border e-commerce and local economy.

It is necessary to deepen the communication between three areas, build information resources sharing platform, establish and improve interest coordination mechanism in order to promote the corporation and create common interests. The three areas shall highlight unique functions, optimize regional economic structure and expand cooperation field. The general characteristics and differentiation are both important. It is necessary to avoid homogeneity competition and realize dislocation development.

\section{B. Improve Quality Control System}

The government shall strengthen and implement quality control system, improve the online and offline supervision and random checking mechanism for cross-border e-commerce products, strictly inspect the small packages and bulk cargo, avoid supervision gap. The cross-border e-commerce is developing towards "light-weight trend", therefore, the inspection and quarantine shall be transformed correspondingly The traditional inspection system shall be changed and the supervision system shall be upgraded.

Establish accountability system to supervise the quality of products. Dispose unqualified or defective products and renovate unqualified enterprises. Make sure the unqualified products would not flow into market. Control the acceptable quality level and reduce the unqualified rate of products. 


\section{Improve Logistics Transportation of Cross-border E- commerce}

\section{1) Improve Logistic Facility Construction}

It is important to optimize and improve the allocation of logistics infrastructure resources and promote and upgrade the logistics industry. Find out resolutions for problems such as low automation level, insufficiency, etc. Improve the automation level, develop multifunctional services, improve transfer facilities construction, and encourage the work efficiency of series of facilities in warehouse, transportation, and distribution and information platform. Improve the transportation by sea, land and air, encourage multimodal transport, and build a reasonable logistics system.

\section{2) Accelerate the Construction of Oversea Warehouses}

The construction of overseas warehouses is conducive to reducing costs. The goods are directly sent to foreign warehouses, which reduces the links and procedures, saves costs, and realizes local sale and local distribution. For customers, oversea warehouses improve the efficiency of flow of goods. Comparing to retail and direct mail, the cost of oversea warehouses can be reduced by $20 \%-50 \%$, the shipping time is shortened from the original 20 days to 3 to 5 days. The logistics cost is also reduced. Oversea warehouses better serve the customs and enhance the competitiveness of cross-border ecommerce enterprises.

\section{Introduce High-quality Interdisciplinary Talents}

\section{1) Introduce Foreign High-quality Talents}

With the rapid development of cross-border e-commerce, high-quality interdisciplinary talents are urgently needed. Talents training could not solve talents shortage. The Free Trade Area shall recruit such high-end talents at home and abroad, and actively encourage and guide high-end talents at home and abroad to work in Fujian. It is necessary to retain talents not only rely on high salaries, but also meet the specific needs of them. Therefore, the enterprises shall communicate with employees, care them, understand their needs and actively encourage employees to make suggestions to enterprises.

\section{2) Cultivate High-quality Talents}

The colleges and universities shall be supported to set specialty of cross-border e-commerce and cultivate professional talents systematically. Fuzhou and Xiamen have many colleges and universities and abundant teaching resources. Pingtan shall be supported by Fuzhou, Xiamen and central government. Each college and university cultivates cross-border e-commerce talents in different ways. On the one hand, it is important to intensify the training of teachers. The teachers shall regularly go to cross-border e-commerce enterprises to learn about the actual operation procedures. The colleges and universities could also construct simulation lab and hire talents from enterprises to teach at the school, so that students can learn and apply the theoretical basic knowledge;
On the other hand, a sharing platform can be established, and all high-quality cross-border e-commerce merchants are invited to come to the platform to share experiences and exchanges. The technicians and experts of various cross-border ecommerce enterprises can be invited regularly to guild and train the actual operation of students and teachers. Specialized guidance and training enable teachers and students to make up for the deficiencies, learn the new trends and technologies of the cross-border e-commerce industry in the first time.

\section{3) Intensify Policy Support}

The government shall establish relevant supportive policies and bonus policies to introduce high-quality talents at home and abroad with financial support, provide high salary and bonus for talents coming to work at Fuzhou, Xiamen and Pingtan. The government shall formulate policies to solve problems for foreign talents, such as housing problem, customs clearance, social insurance problem, visa and children's education, etc. The welfare policy make talents working in Free Trade Area have strong sense of belonging, and attract more foreign interdisciplinary talents coming to work at Fuzhou, Xiamen and Pingtan.

\section{CONCLUSION}

As a coastal province of China, Fujian has inherent geographical advantages. Therefore, it is an important province for foreign trade in China. Fujian Free Trade Area is established in 2015, including Xiamen, Fuzhou and Pingtan with favorable environments. Under the trend that cross-border e-commerce has become a new mode and new form for China's foreign trade development, Fujian Province is also committed to developing its own advantages and developing cross-border e-commerce. The three areas included in Fujian Free Trade Area are very beneficial to the development of cross-border ecommerce. Fuzhou and Pingtan have successively become "cross-border e-commerce pilot cities". In recent years, crossborder e-commerce in Fujian Free Trade Area has been developing rapidly; however, there is still a large gap with provinces which have advanced cross-border e-commerce, such as Guangdong, Jiangsu and Zhejiang.

Fujian Free Trade Area shall make use of its advantages and promote the development of cross-border e-commerce. Fujian Free Trade Area will greatly drive the development of cross-border e-commerce in Fujian. Cross-border e-commerce has new trade mode and provide opportunities for enterprises to go abroad and optimized the export structure. Fujian Free Trade Area shall take the opportunities, support the crossborder e-commerce to drive the development of Fujian in "Internet +" new normal and take control of the whole crossborder e-commerce market. It is necessary to establish selfowned brand with high quality and high value-added. Fujian Free Trade Area shall combine its own advantages with the development of cross-border e-commerce and make contributions to the economic development in Fujian. 


\section{REFERENCES}

[1] Zhiyu Fang. Research on Development of Cross-border E-commerce in Fujian and ASEAN under Perspective of Maritime Silk Road [J]. Foreign Trade,2015(10):4-6.

[2] Miaoqian Zheng, Yang Cao, Yibao Zheng. Review of Accelerate the Development of Cross-border E-commerce of Fujian [J]. E-business Journal,2014(10):13.

[3] Lanting Zeng, Xiaojing Liu. Competitiveness analysis of cross-border ecommerce industry in Pilot Free Trade Areas based on diamond model_ With examples from Shanghai, Guangdong, Fujian and Tianjin[J].Journal of Fujian Agriculture and Forestry University (Philosophy and Social Sciences), 2017,20(02):29-33.

[4] Liang Zeng. Comparative Study on Cross-Border Electronic Commerce between Fujian Province and Zhejiang Province [J]. Journal of Huanghe S\&T University,2017,19(01):105-111.

[5] Huapeng Jiang. Thinking on Foreign Languages Major Reform in Higher Vocational Colleges_- Taking the Development and Effect of Cross Border E-Commerce in Fujian Free Trade Area as Example[J].Journal of Nanping Teachers College,2017,36(04):79-85.

[6] Xiaowei Lin. Research on Development Patterns of Cross-border Ecommerce in Fujian Free Trade Area.[J].Journal of Zhangzhou Teachers College (Philosophy \& Social Sciences),2017,31(03):38-45. 